\title{
ETERNAL LIFE AND THE COMMON GOOD: WHY LOVING ONE'S NEIGHBOUR MATTERS IN THE LONG RUN
}

\author{
Christopher Marshall*
}

The duty to "love one's neighbour as oneself" has been carried over from the biblical tradition into subsequent moral and legal philosophy, as a helpful way of signalling commitment to the common good. When secular theorists appeal to this principle, they typically strip "love" of its emotional intensity and sacrificial dimensions and reduce the principle of "neighbour-love" to the negative duty of not interfering unduly with the rights and freedoms of others. But if we consider what Jesus understood neighbour-love to involve, as evident particularly in his dialogue with a Jewish lawyer in Luke 10:25-37, an altogether more demanding or thicker conception of the common good emerges.

\section{INTRODUCTION}

The theme of our conference was "Recovering the Common Good". It needs recovering presumably because generations of political, social and moral liberalism have so stressed the supremacy of individual rights and freedoms that we have lost hold of perhaps the most important truth of biblical anthropology - which is that human beings are fundamentally social creatures, made in God's own image, for relationships of mutual responsibility and reliance, both with God and with one another.

This understanding of human solidarity emerges clearly in the two accounts of creation in Genesis $1-2 .{ }^{1}$ In both accounts, there is a fascinating shift from singular and plural categories in the depiction of human origins. On the one hand, God creates an individual human creature in his own image. In Genesis 1, other creatures are created in multiplicities - "waters", "lights", and "plants", "swarms of living creatures", "birds", "animals" and "fish". But then God creates a solitary earth

* Professor, Religious Studies Programme, Victoria University of Wellington.

1 New Revised Standard Version (NRSV). 
creature, "Adam" (1:26). The noun is singular and generic and, although it is indicated that Adam consists of many individuals ("male and female he created them" (1:27), "let them have dominion" (1:26), their plurality springs from their generic unity as Adam or "humankind". The individuality of Adam is even more obvious in Genesis 2, where God forms a single being out of the dust of the ground and only subsequently introduces sexual differentiation from a constituent part of him.

Later Jewish rabbis were intrigued by this emphasis on Adam as a singular being. They took it to be an indication of the unique worth of every distinct person, irrespective of race, rank, class or religion. Each and every human being is equivalent to that first human created by God and thus of inestimable value. Accordingly they said: ${ }^{2}$

Whoever harms a single person is as if they harmed all of God's creation. Whoever benefits a single person is as if they had benefited all creation. Indeed, each of us, equivalent to that first ancestor, is entitled to boast, 'On account of me was the world created'.

This affirmation, in creation, of the enduring dignity of every single human person provides the profoundest justification imaginable for the existence of individual human rights and freedoms something far more profound than anything secular tradition can afford. The possession by every person of inalienable human rights is literally a "status symbol" - a symbol of their status as bearers of God's image.

Yet, at the same time, both creation accounts also make it clear that humanity necessarily implies co-humanity: "In the image of God he created him, male and female he created them. God blessed them and said to them, 'Be fruitful and multiply'" (Genesis 1:27-28). In Genesis 2, the very reason why woman is created is because God recognises, "it is not good that the man should be alone; I will make him a helper as his partner". When the man first meets the woman, formed from his own rib, he joyfully cries out, "This at last is bone of my bones and flesh of my flesh" (2:18-24).

The implication here is clear: it is impossible to be human alone. Human beings are not constituted as isolated, self-contained atoms, but as persons-in-community. Sociality or relationality is intrinsic to human nature. It is intrinsic because it is of the nature of the Creator God to be in relationship, not only with his creatures, but also within God's very own being. From a Christian Trinitarian perspective, God's "personality" consists in being a communion of persons: "let us make humankind in our image" (Genesis 1:26). Just as the Triune God exists in eternal, intimate, equalitarian relationship within the Godhead, so too are human beings created to know intimate, enduring, equalitarian relationships with one other. Accordingly, as Jürgen Moltmann has stated,

2 Daniel F Polish "Judaism and Human Rights" (1982) 19 Journal of Ecumenical Studies 40 at 41. 
"Only in human fellowship with other people is the human person truly an image of God" (Genesis $1: 28){ }^{3}$

Now, if the biblical affirmation of individual human dignity provides the securest foundation possible for the existence of universal human rights, its affirmation of our constitutional cohumanity furnishes the firmest foundation for the existence of social responsibilities and duties. ${ }^{4}$ God's panicky question to Cain, "Where is your brother Abel?" and Cain's dismissive response, "I don't know... Am I my brother's keeper?" dramatically underscores the inescapable nature of our responsibility for the welfare of our fellow human beings (Genesis 4:9). Such responsibility needs no utilitarian defence; it is of the very essence of our human identity as God's image bearers. It follows, then, that discharging our duties and social obligations to others should not be understood, as it is in the secular liberal tradition, as a regrettable but necessary restriction or limitation on our natural freedom; it is in fact the very means of realising our freedom.

\section{RESPONSIBLE FREEDOM}

The biblical understanding of human freedom differs significantly from the understanding of freedom in the post-Enlightenment liberal tradition. Political and social liberalism conceives of freedom principally in terms of freedom from all avoidable external constraints and the freedom of private citizens to do as they choose, as long as they do not violate the liberty of others. The biblical-Christian view of freedom, in contrast, views freedom as a state of being more than a state of doing; an inner reality more than outer reality; a freedom of purpose more than freedom of choice; a freedom found in subjection, not a freedom from subjection - a subjection, that is, to the will and rule of the Creator.

Fundamentally, freedom in biblical understanding is the freedom to be fully human, the freedom to be the kind of creatures God intended us to be. And since human creature-hood is inherently social or relational in nature, individual freedom can never exist apart from social responsibility. We are only truly free as individuals when we use our freedom to serve the common good, when we fulfil our responsibility to be our brother's and sister's keeper.

According to the Christian gospel, the definitive experience of such freedom is found in voluntary surrender to the lordship of Jesus Christ. Through his death and resurrection, Christ sets human nature free from its servitude to the alien powers of law, sin and death and, through the gift of the Spirit, enables believers to rediscover their true destiny as image bearers, made for relationship with God and with others. "So if the Son makes you free", Jesus said, "you will be free indeed" (John 8:36). Writing to the Galatians, the apostle Paul declares, "For freedom Christ has set

3 Jürgen Moltmann On Human Dignity: Political Theology and Ethics (Fortress Press, Philadelphia, 1984) at 25.

4 See generally Christopher D Marshall Crowned with Glory and Honor: Human Rights in the Biblical Tradition (Pandora Press, Telford, Pennsylvania, 2001). 
us free. Stand firm, then, and do not submit again to a yoke of slavery" (Galatians 5:1). Importantly, he goes on to explain:

For you were called to freedom, brothers and sisters; only do not use your freedom as an opportunity for self-indulgence, but through love become slaves to one another. For the whole law is summed up in a single commandment, 'You shall love your neighbor as yourself.' (Galatians 5:13-14)

Paul summons his readers to use their freedom to seek and to serve the common good. The purpose of God's entire law, Paul says, can be "summed up in a single commandment, 'You shall love your neighbor as yourself."' (Galatians 5:14). He makes the same point in Romans 13:

Owe no one anything, except to love one another, for the one who loves another has fulfilled the law. For the commandments, "You shall not commit adultery, You shall not murder, You shall not steal, You shall not covet," and any other commandment, are summed up in this word: "You shall love your neighbour as yourself." Love does no wrong to a neighbour; therefore love is the fulfilling of the law (Romans 13:8-10).

This duty to "love one's neighbour as oneself" has been carried over from the biblical tradition into subsequent moral and legal philosophy, as a helpful way of summarising and characterising our social responsibilities to one another. Admittedly, this is much less common today than it once was, due mainly, one suspects, to the current ascendancy of rights language in public discourse and the assumption that rights talk can do the whole job of social morality. But significantly, when philosophers or jurists or politicians appeal to the "love of neighbour" principle as a way of signalling commitment to the common good, they typically strip "love" of its emotional intensity and sacrificial dimensions, and reduce the principle of "neighbour-love" to the negative duty of not interfering unduly with the rights and freedoms of others. On this understanding, to "love one's neighbour" primarily means to respect the other person's autonomy and freedom of action and to do no wrong to them.

This is all very well and probably as much as statutory law can reasonably require of citizens in terms of balancing individual freedom and social responsibility. But if we turn our attention to what Jesus understood neighbour-love to involve, we find an altogether more demanding or thicker conception of commitment to the common good. This is evident in one of the key passages in the gospel tradition that was responsible for neighbour-love acquiring such huge importance in Christian (and secular) ethics. ${ }^{5}$

5 The following discussion is drawn from my new book, Compassionate Justice: An Interdisciplinary Dialogue with Two Gospel Parables on Law, Crime, and Restorative Justice (Cascade Books, Eugene (Oregon), 2012) at 55-81. The impact of this biblical text on the evolution of Western law, including Lord Atkin's celebrated appeal to it in 1932, is discussed at 147-149. 


\section{WHAT MUST I DO TO INHERIT ETERNAL LIFE?}

In chapter 10 of his Gospel, Luke recounts an occasion when "a certain lawyer" (nomikos tis) approached Jesus with the question, "What must I do to inherit eternal life?" (10:25-37). In the firstcentury Jewish context, the lawyer would have been a Torah scholar, that is, an expert in the texts and legal traditions of Judaism. The fact that he "stood up" to ask his question, and salutes Jesus courteously as a "teacher", suggests he has been seated amongst those whom Jesus has just been instructing. The question he asks was probably commonplace in religious discussion of the day, and it is likely that Jesus was well known for discoursing on it. ${ }^{6}$

As a specialist in the Law of Moses, the lawyer would have naturally assumed the answer to his question resided in the Torah. But where precisely? How was God's law to be rightly understood and obeyed? He was presumably hoping to elicit from Jesus a summary of the Torah's most fundamental or ineluctable requirements, perhaps captured in a single paradigmatic commandment, the fulfilment of which would comprehend all other precepts in the law and thus guarantee access to eternal life.

Jesus responds to this question with a counter-question that invites the lawyer to nail his own colours to the mast: "What is written in the Law?", he asks. "How do you read it?" (Luke 10:26). In reply, the lawyer brings together two widely separated commandments in the Pentateuch: the Shema from Deuteronomy 6:4-5, which faithful Israelites were expected to recite twice a day, and the formulation of the Golden Rule in Leviticus 19:18:

He answered, 'You shall love the Lord your God with all your heart and with all your soul and with all

your strength and with all your mind, and your neighbour as yourself'.

There are three features of this interchange worth noting. First, it is the Jewish lawyer, not Jesus, who nominates the love commandments as the law's centre of gravity; secondly, in doing so, he conflates two distinct commandments into a single unitary obligation; and thirdly, he construes this obligation to be principally a matter of ethical obedience rather than emotional experience. Each point warrants further comment.

\section{A The Question of Originality}

The first thing to note is that it is the lawyer who offers the twin love commandments as the heart and goal of the law's teaching and the key to eternal life. This insight is not depicted as a hermeneutical innovation on the part of Jesus. It comes, instead, from the cross-examining, and somewhat hostile, Jewish lawyer. This may come as a surprise to many Christians, who usually credit Jesus with this original insight. Indeed enormous scholarly effort has been expended trying to prove that Jesus' teaching on the double love commandments was innovative or unique. To be fair, the evidence is complex and difficult to assess, and there are certainly distinctive features about

6 See also Luke 18:30; Mark 10:30; and Matthew 19:29 and 25:46. 
Jesus' teaching on the subject. But none of the biblical accounts ever suggests that Jesus was alone in recognising the pre-eminence of the twin love commandments. Certainly, Luke has absolutely nothing invested in implying that Jesus' perspective was in any way novel or original. It was, he implies, a common understanding shared, not only by Jesus and his supporters, but also by his critics and opponents.

\section{$B$ The Conflation of the Twin Commands}

This leads to the second observation on the episode. In answering Jesus' question, the lawyer conflates two distinct commandments into a single unit without differentiation, governed by a single verb: "You shall love the Lord your God with all your heart and soul and strength and mind... and your neighbour as yourself" (Luke 10:27).

In the other gospel tradition involving the love commandments - the dialogue between Jesus and a scribe in Jerusalem in Mark 12 - the situation is different. There, love for God is identified as the "first" and "greatest" commandment, and love of neighbour as "the second" commandment (Mark 12:28-31; Matthew 22:38-39). This hierarchical enumeration of "first" and "second" keeps the two commandments quite distinct. Love for God is given absolute primacy; love for neighbour comes second in importance, though it remains inseparably linked with the first.

But this hierarchical enumeration does not occur in Luke's episode. Here the lawyer blends the two commandments into a single obligation, controlled by a single imperative. Moreover, Jesus endorses this amalgamation: "You have given the right answer", he says. "Do this [not, do these], and you will live" (Luke 10:28). The two commandments are not simply juxtaposed; they are effectively combined, a combination Jesus would later exploit in a parable.

What are we to make of this? The inference seems to be that love for God includes and enables love of neighbour, while love of neighbour expresses and requires love for God. There can be no love for God without love for neighbour, and no love for neighbour that does not involve pleasing or obeying God. To love God with the totality of one's physical, moral, intellectual and emotional capacities requires loving one's neighbour as well, and loving one's neighbour is an integral part of one's wholehearted response to God. God cannot be loved in isolation, but only in and through loving other people.

\section{Love as Ethical Obligation}

This brings us to the third observation. The "love" that Scripture speaks of in all this is primarily a volitional and moral commitment, not an emotional experience. After all, if God commands people to love, then love must be, first and foremost, a matter of formal obedience. It is not a case of having warm, fuzzy feelings towards others, which cannot be ordered into existence anyway, but rather a case of willing and doing what is necessary to secure the other's welfare.

Once more, this is something Jesus and the Jewish lawyer agree on. The lawyer asked: "What must I do to inherit eternal life?" Jesus responds by prompting him to recite the love 
commandments, then says: "Do this and you shall live". Love is something to be done, not something to be felt. Love for God is to be done by obeying God's will. Love for neighbour is to be done by acting in the neighbour's best interests. Both parties concur on this. But, for the first time in our story, a crack begins to open up between them on two other more consequential matters namely, on the extent to which love should go on behalf of its object, and on how inclusive love's object should be. On these two matters, Jesus sets a new high watermark, one that, I suggest, radically redefines the meaning of neighbour love and duty to the common good.

Now, remember that Jesus' interrogator is a lawyer, and a very good lawyer at that. Like all lawyers, he wants to nail down his terms, and as a good lawyer he pays very careful attention to the actual wording and context of the relevant legislation. The law stipulates that he must love his neighbour as himself, and Jesus confirms that by doing so he will gain eternal life. "But", the lawyer inquires, "who precisely is my neighbour?" (Luke 10:29).

This seems to be a perfectly reasonable question - and one that close attention to the commandment's original setting in the Bible can easily answer. It is crystal clear in Leviticus 19 that the term "neighbour" refers to fellow members of the covenant community of Israel. It designates not just those who live in close physical proximity but those who share in full covenantal status. Accordingly, to "love one's neighbour", in Leviticus 19, does not mean to act benevolently towards all human beings in general. It means to uphold and protect the rights, dignity and status of all those within the covenant community of Israel. In short, the "neighbour" of the original commandment is a fellow Israelite, and the lawyer, as a Torah scholar, considers this definitional point to be critically important.

For Jesus, however, the key issue in Leviticus 19 is not the definition of the noun "neighbour", it is the meaning of the verb "love". Neighbours, according to Jesus, are not created by accident of birth, or nationality, or religion, or law; they are discovered through love. When love is present and active, identification of neighbours takes care of itself. According to the rule of love, we stand in neighbourly relationship to every person we encounter, irrespective of any secondary status that law or religion, culture or ethnicity, and nationality or creed might or might not confer upon them.

It is here then, that Jesus differs from the lawyer. Both accept that love of neighbour sums up God's law and is essential for eternal life. But whereas the lawyer thinks the critical issue in the commandment is the scope of the term "neighbour", Jesus considers it to be the scope of the term "love". The lawyer reduces love to its legal minimum by restricting the category of "neighbour" to fellow members of his own religious community. Jesus, however, maximizes the category of neighbour because he refuses to limit the demands of love. Neighbours are not chosen or created by religion or nationality; they are found through human encounter. And because love of neighbour is inseparable from love of God, there can be no exceptions to love's attentiveness and no limits to what love requires. 
How, then, does Jesus convey his new, radically extensive understanding of neighbour love? Not by means of abstract philosophical reflection, or by exegetical-linguistic debate, but by telling a story - the story of the Good Samaritan - an imaginary little tale that operates on multiple levels and that teaches many lessons (Luke 10:30-37).

\section{A PARABLE OF NEIGHBOUR LOVE}

The parable is familiar to us all. It tells of a man who is brutally assaulted on a journey from Jerusalem to Jericho and left for dead on the side of the road. Two passing temple officials notice the unconscious man in the ditch. But instead of stopping to help him, they cross to the other side of the road and carry on their way. Next a travelling Samaritan chances upon the victim. He is "moved with compassion" at what he sees (Luke 10:33). He bandages the victim's wounds, lifts him on to his own donkey and transports him to a nearby inn, where he takes care of him overnight. The following day, the Samaritan must resume his journey, but not before paying the innkeeper in advance to continue nursing the injured man back to health, and promising to reimburse him for any other expenses he might incur.

The depth and richness of this story are virtually limitless (in Compassionate Justice I devote over 200 pages to its analysis). ${ }^{7}$ But here I shall highlight two striking features of the narrative relevant to our theme - its role not only in extending the scope of the term "neighbour", but also in radicalising the quality of love owed to neighbours, and the critical role neighbour-love plays in securing eternal life. This projects the concept of the common good onto a very long-term timeframe.

\section{LOVE AS AN ALL-ENCOMPASSING RESPONSIBILITY}

I said a moment ago that the "love" the biblical commandments speak of is primarily a volitional and activist commitment, not an emotional experience. Commentators frequently belabour this point, with a palpable sense of relief. They note, for example, that it is only by understanding love in non-emotional terms is it possible to make sense of the injunction to "love one's enemies" (Matthew 5:43-48; Luke 6:27-28). Love of enemy cannot be a feeling because enemies, by definition, are those for whom you do not feel tenderness or affection or warmth. We love our enemies, not by caring deeply for them, but by refraining from harming them, or hurting them or killing them. We have also seen how a similarly restricted notion of love applies in the political tradition as well. Citizens love their neighbours, not by feeling love for them, but by not interfering with their rights, freedoms and security.

Now to posit with such a thin conception of love is, arguably, simply being realistic, and it is not inconsistent with the biblical understanding of love as an action more than a sentiment, something done more than something felt. But the parable of the Good Samaritan suggests that, for Jesus at 
least, there is more to love of neighbour than mere goodwill alone. The Samaritan's extraordinary actions in the parable - which are recounted in exquisite detail - are the direct result of him being emotionally "moved with compassion" at what he saw (Luke 10:33). This verb denotes a stirring in his innards, a gut-wrenching surge of emotion that propelled him into action. The love he displayed was more than a clinical, cold-hearted compliance to the dictates of moral law: it was a passionate, sympathetic sharing in the victim's personal suffering and isolation. The Samaritan did justice to his legal and moral obligation to love his neighbour as himself by feeling love and by acting in accordance.

For Jesus, then, neighbour-love is more than showing respect for the equal rights and freedoms of others. It is, instead, a love patterned after our love for God. Just as love for God cannot be reduced to right intention alone or the mere avoidance of wrongdoing, it is all-encompassing in its reach, engaging the entire heart, mind, soul and strength. So, love for neighbour cannot be limited to external posture alone, but involves feelings, thoughts and motivations as well. This is an important consequence of the amalgamation of the two love commandments into a single command, governed by a single verb. It implies that love for one's fellow human beings demands the same intensity and dedication of love that we have for God. The whole-heartedness of love for God enjoined in the Torah must also be extended to our neighbours as well. Both God and neighbour are to be loved with the entirety of one's heart, mind, soul and strength. In both cases, the love entailed is volitional, rational, practical and emotional in character.

The Samaritan exemplifies this truth. On being "moved with compassion" at what he encountered, he engaged all the powers of his personality - his sight, his heart, his hands, his strength, his time, his possessions and his intelligence - to meet the needs of his neighbour. His display of love exceeded mere charity; it was unreserved in its passion and commitment and costliness.

Of course, this immediately raises the question: whence comes such all-encompassing love for others? Whence comes such intensity and generosity of human love that universalises neighbours to include even enemies and displays wholehearted dedication to meeting their needs? Ultimately, it comes only from God, who is the source of all love. It can come only from knowing and understanding and experiencing the love of God in all its limitless depths and boundless grace, and being empowered by this experience to love our neighbours in similar measure.

This, then, is the main take home lesson of this parable for our conference theme. Recovering the common good requires a collective rediscovery of our fundamental social obligation to love our neighbours as ourselves. Additionally, it requires recognition that this love far exceeds some minimal respect for our neighbour's legal rights and liberties and instead requires us to seek their full flourishing and belonging with every fibre of our being. Modern law, of course, cannot demand such dedicated commitment from its citizenry. But biblical law does. Nor can public policy generate such love in the hearts of people. But the Spirit of Jesus can and always seeks to do so primarily amongst those who are consciously open to his presence and power. 


\section{LOVING TO ETERNAL LIFE}

The second take home lesson is even more mind-boggling. The lawyer asked Jesus, "Who is my neighbour?" (Luke 10:29). Jesus recounts the parable of the Good Samaritan, then asks the lawyer: "How does it seem to you? Which of these three do you think was a neighbour to the man who fell into the hands of robbers?" (Luke 10:36). This question returns to the lawyer's original inquiry, but in a significantly modified form. It no longer focuses on the identity of the other as neighbour, but on the questioner's own identity as a neighbour. It is not, "Who is my neighbour?" but "To whom am $I$ a neighbour?" There is a shift from object to subject, from recipient of compassion to agent of compassion, from defining the rights of others to acknowledging one's own responsibilities.

So which of the three men, Jesus asks, acted like a neighbour to the man in the ditch? Posed this way, only one answer is possible, for only one of the three characters did anything at all to benefit the victim. "The one who did mercy", the lawyer replies. The lawyer had initially asked Jesus what he must "do" to win eternal life (Luke 10:25), and Jesus had responded he must "do" the law (Luke 10:28). By indicating that the Samaritan "does" mercy, the lawyer implies that he meets the requirement of "doing" the law, which thus opens the door to eternal life to him (10:37). Jesus confirms this by saying to the lawyer: "Go and do likewise" (10:37). The verb 'to do' occurs no fewer than four times.

The message of the parable, then, is plain: commitment to serving the common good, through the continual practice of what I call "compassionate justice" to those most in need, is an essential requirement for gaining entry to the age to salvation. The Samaritan qualifies to enter; the priest and the Levite do not. It appears, then, that love of neighbour, no less than love of God, has eternal consequences. It matters in the long run that we recover our commitment to the common good. 